\title{
A MODEL FOR CLINICAL EVALUATION
}

\author{
M. Mulder
}

\section{OPSOMUING}

Na jarelange wowsteling met die problemgtiel van kithtese evaluering en in bewuswording van dte belangrlikeid vin hierdie aspek van die thiniese

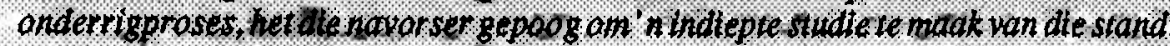
von klinlese evetuering in verpleeghunde. Die studle is pedurende die tweede semester van 1900 ondernem.

Die belangrtiste bevindinge van tierdie novorsibg is in 'n vortige artikel bespreek

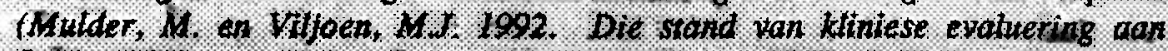

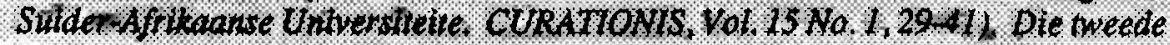
daetstelling van die smitie noomith die opstel van 'n proto-teoretiese modlel vir ktiniese evatuering word in bierdie artiket behandt.

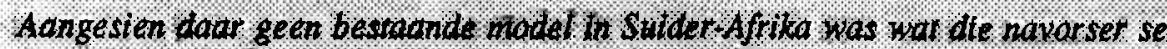

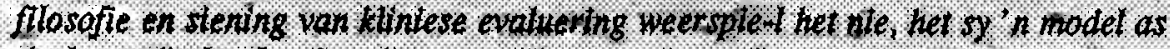

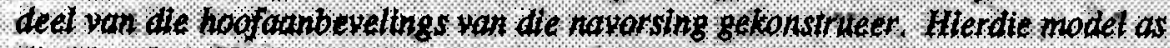
de idecal vir kintese evaluering vorrgehou.

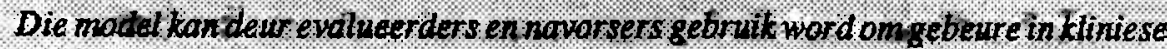
evaluering te beracm, te bepton, te implementeet, te remedieer en omp probleme in

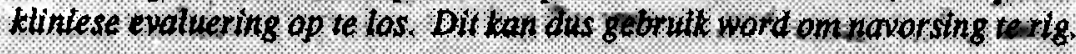

\section{SUWHARY}

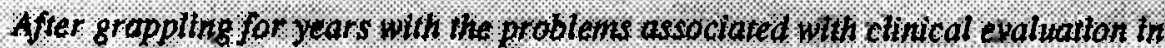
nursing. and beconing thereasing y aware of the inportance of this aspect of the clinical reaching process, the reaparcher resolved to make on indepth stuty of the stare of etinical wotwation in nmesing. The strity whs whdertaken in the second semester of 1990.

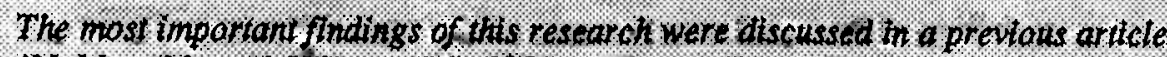

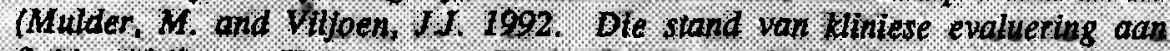

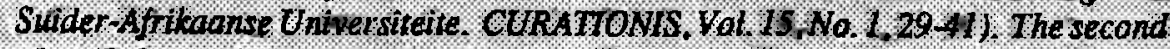
aim of the study. i.e. the develophent of a proto theoretical model for chinicat evaluatian, is tiscenssed in this article.

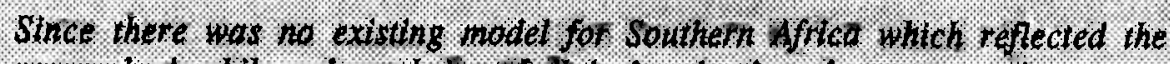

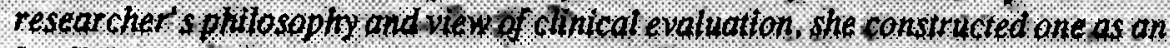
implicityart of the main recommendations of the rescarch. This model is presented as the ideal for cthicat evaluation.

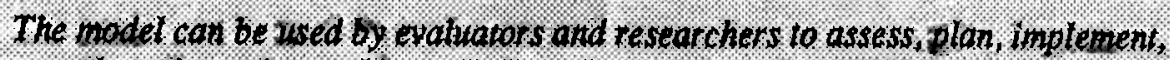
remedy and to solve problems of flnteal eveluation. 1 can also be used to dhect futw r rescarch

\section{INTRODUCTION}

After grapp.ling for years with the problems associated with clinical evaluation in nursing, and becoming increasingly aware of the importance of this aspect of the clinical teaching process, the researcher resolved to make an indepth study of the state of clinical evaluation in nursing.

No existing model for Southern Africa reflects the researcher's philosophy and view of clinical evaluation, therefore one constructed by the researcher is presented as appropriate for clinical evaluation.

The model can be used by evaluators and researchers to assess, plan, implement, remedy and to solve problems of clinical evaluation. It can also be used to direct future research.

\section{ORIGIN OF THE MODEL}

The following non-purposeful and purposeful exposures collectively contributed to the construction of the model:

- Experience of clinical practice.

- Experience of nursing education.

- A reconnaisance phase (penetrating talks with experts, attending nursing education congresses, etc.).

- The compilation of a frame of reference regarding the state of clinical evaluation in departments of nursing in Southern Africa.

- A critical analysis of the collected data. Inductive and deductive reasoning was used in the construction of the model.

\section{TYPE OF MODEL}

The researcher regards the model as proto-theoretical model as described by Gorrel (quoted by Mouton et al. 1988:141).

In this way Gorrel tries to indicate that most models in the humanities (unlike the natural sciences) have the character of a precursor - that is, they precede theories.

According to Gorrel a proto-theoretical model has four characteristics which will:

- identify problem areas or questions about the phenomenon to be researched;

- order, curtail, isolate and simplify the domain to be studied;

- provide scientific concepts with new definitions;

- provide visual representations of the domain under study, as well as the means by which forecasts can be made (Mouton et al, 1988: 142). 


\section{LMMTS OF THE PROPOSED MODEL}

The model can be used for any basic ${ }^{l}$ nurse training programme for which students have to master clinical skills and develop certain personality traits.

\section{THEORETICAL EXPLANATION OF CLINICAL EVALUATION}

\section{Definition}

Clinical evaluation is a systematic process which takes place continuously, and during which a professional (competent) value judgement is made of the clinical competencies and personality traits of a student nurse in terms of valid and reliable evaluation methods and techniques against previously formulated objectives (Kruger 1980:25; Reilly 1980:91; Uys, 1982:73-90; Mellish \& Johnston 1986:2, 6-28). This evaluation takes place outside the formal didactic situation in a real or simulated practice setting or only in actual clinical practice (Litwack et al. 1972:41).

\section{Clinical evaluation is a systematic process}

The process of clinical evaluation comprises four phases:- assessment, planning. implementation and remedial action. The concept of remedial action was specifically chosen because the concept of evaluation could be confusing in the context of clinical evaluation.

The complex nature of clinical evaluation makes it imperative for all evaluators to be actively involved in all four phases. A team approach should be followed (Kehoe \& Harker 1979:88; Robertson 1980:13; Guilbert 1981:2.40, Ewan \& White 1984:216 -217). This will provide a common goal and ensure that the knowledge, experience and skills of all the participants will be employed to the advantage of the primary objective. Activities will be coordinated, interdependent problems will be addressed and communication among team members will be promoted.

\section{Assessment}

The assessment phase consists of a thorough situation analysis during which the following aspects must be addressed:

- The requirements of the professional statutary body.

- Other environmental influences such as the needs of the health and educational authorities, political and economic forces, the needs of health care consumers, technological development and so forth.

1. A training programme leading to registration in the basic qualifications - general, prychiatric and community nursing and midwifery.

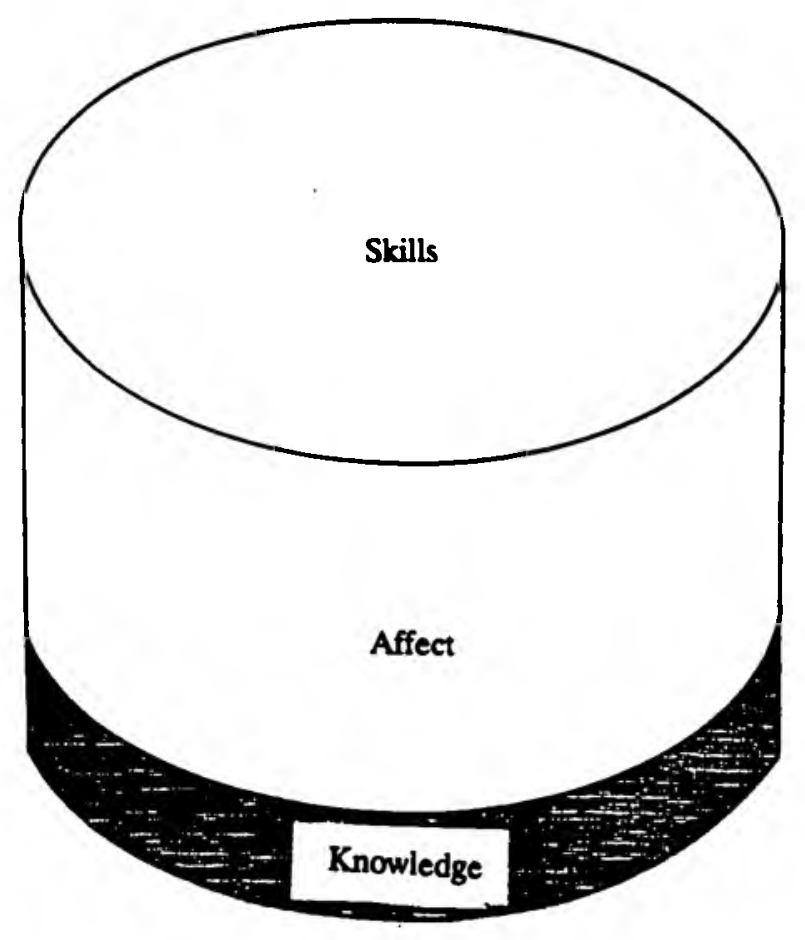

FIGURE 1: A DIAGRAMMATIC REPRESENTATION OF THE FACETS WHICH COMPRISE CLINICAL COMPETENCE AND THEIR MUTUAL RELATIONSHIP

- The philosophy of the training school.

- The clinical teaching goals or objectives of the training school.

- The resources, expertise and assets at the disposal of the training school. (For instance accessible health care institutions; a simulation laboratory; audio-visual equipment; computer aided teaching programmes; educationists who have the necessary experience and knowledge of clinical evaluation, etc.).

- Subsystems within the training school or tertiary educational institution such as a student guidance centre (Uys 1982:21-30).

\section{Planning}

Careful planning is the foundation of effective evaluation. During this phase clinical objectives must be formulated or existing objectives must be revised in the light of the situation analysis. The way in which clinical objectives are to be reached must be carefully planned. In other words, learning opportunities must be scheduled. Other aspects to be considered are:

- What is the rationale for clinical evaluation?

- Who will evaluate whether the students have reached their clinical objectives?

- Is formative or summative and formative evaluation jointly, to be used?
- What combination of evaluation methods and techniques are going to be applied?

- Are students going to be evaluated in actual and simulated clinical practice or only in actual clinical practice?

- How are students going to be involved in the clinical evaluation process?

- How is feedback going to be given to students?

After these decisions have been made they are set out in a clinical evaluation plan which serves as a blueprint for action as well as a framework for remedial action.

\section{Implementation}

Clinical evaluation must take place in a favourable climate of mutual respect, cooperation, sincerity and frankness between the evaluator and the student (Litwack et al. 1972:vii; Reilly 1980:93-99). Only then will the evaluator be able to provide the student with the necessary understanding and support.

Clinical evaluation therefore focuses on the student's progress and associated needs. The evaluator must distinguish between time for instruction and time for evaluation. This will ensure that the student is evaluated informally and receives the necessary guidance and feedback until such time as the evaluator and student jointly decide that the student is ready for formal evaluation (Gentile \& Stevens-Haslinger 1983:49; Jackson 1987:384-385; Flagler et al. 1988:345). 
Students must take an active part in the clinical evaluation process and must apply self-evaluation (Woolley 1977:311; Sommerfeld \& Accola 1978:435; Fuhrmann \& Weissburg 1978: 139; Woolf 1984:78-80; Abbot et al. 1988:222). They must be given feedback on both positive and negative aspects of their clinical competence immediately after being evaluated. They must cooperate with the evaluator in deciding on remedial actions and a deadline must be set. In this way evaluation becomes a process of development and a course in mastering clinical competencies.

The ideal would be to expose students to the minimum number of evaluators in order to promote the development of a relationship of trust which is essential for professional socialization. Such a relationship is characterized by trust, sensitivity, empathy and confidentiality.

Empathy is imperative. The evaluator must be able to put herself in the student's situation and "experience" the emotions of the student. The evaluator must, however, keep her identity and must be able to remain objective in onder to observe accurately.

\section{Remedial Action}

Despite being the last aspect to be discussed, this phase is an integral part of implementation and the two can hardly be separated. Remedial action must be instituted on a continuous basis to promote mastery of clinical skills and personal development (Reilly 1980:90). To wait until the end of the academic year or course and to remedy faults in the following planning phase would be ineffective (Mellish \& Johnston 1986: 6-28).

This four phase process can be represented as a cycle within a cycle (see Figure 4). The student is actively involved to a greater extent in the implementation and remedial phases, that is, in the smaller cycle, while the evaluator is active throughout the entire process.

Remedial action is not, however, applicable only to students. Clinical instruction as such is also evaluated and also requires remedial action to eliminate deficiencies.

\section{Clinical evaluation takes place continously}

It is not the end of the teaching-learning process. It is not a unilateral, occasional event, but a daily interaction between evaluator and student during which the student is formed professionally and as a skilled nurse.

In order to attain this goal, registered nurses in clinical practice must, of necessity, also act as evaluators. While the nurse educator has the expertise and experience of nursing education and can function as the team leader and initiator in this regard, the registered nurse has expertise and experience of clinical practice (Kehoe \& Harker 1979:43,50-51; Kane 1980:22; Mellish \& Johnston 1986:30;
Anderson \& Knuteson 1990:42-43).

Clinical evaluation is a professional, competent value judgement of the clinical competence and personality traits of the student nurse.

\section{Professional value judgement}

This implies that the evaluator is authorized to evaluate by a legally constituted body which may be a professional statutary body, a training school or a health authority. A professional value judgement also implies that the evaluator must have the competence required to evaluate (Mellish \& Johnston 1986:1).

The evaluator must be thoroughly grounded in the following aspects of clinical evaluation:-

- The formulation of clinical aims and objectives.

- Factors to be taken into account when planning clinical evaluation.

- The development of valid and reliable evaluation instruments.

- Communication skills, including assertive behaviour and therapeutic communication.

- Factors that may influence impartiality.

- Requirements for the climate in which clinical evaluation is to take place.

- Knowledge of the various evaluation methods and techniques and their implementation.
- Coping with the practical problems which may arise during clinical evaluation (Kehoe \& Harker 1979:57-58; Karuhije 1986:140; Mellish \& Johnston 1986:32-33).

Because evaluation is a value judgement it is not only the application of a given rule or principle. It is a cognitive process in which the evaluator measures and comes to a decision by a process of logical reasoning.

\section{Clinical competence}

Clinical competence includes three facets, i.e. knowledge, skills and affect, which are necessary for successful fulfilment of the professional nursing role (see Figure 1).

A. Knowledge comprises factual knowledge and knowledge gained by experience. The latter forms a theoretical basis for skills and affect (see Figure 1). The student's ability to apply this knowledge in clinical practice must be gauged during clinical evaluation.

B. Skills have five components, namely higher cognitive skills, communication skills, action skills, management skills and social skills (see Figure 2).

Higher cognitive skills include the ability to evaluate, synthesize, analyze and solve problems.

Communication skills means skill in the process of conveying information. It includes the verbal and non-verbal aspects of transmitting information.

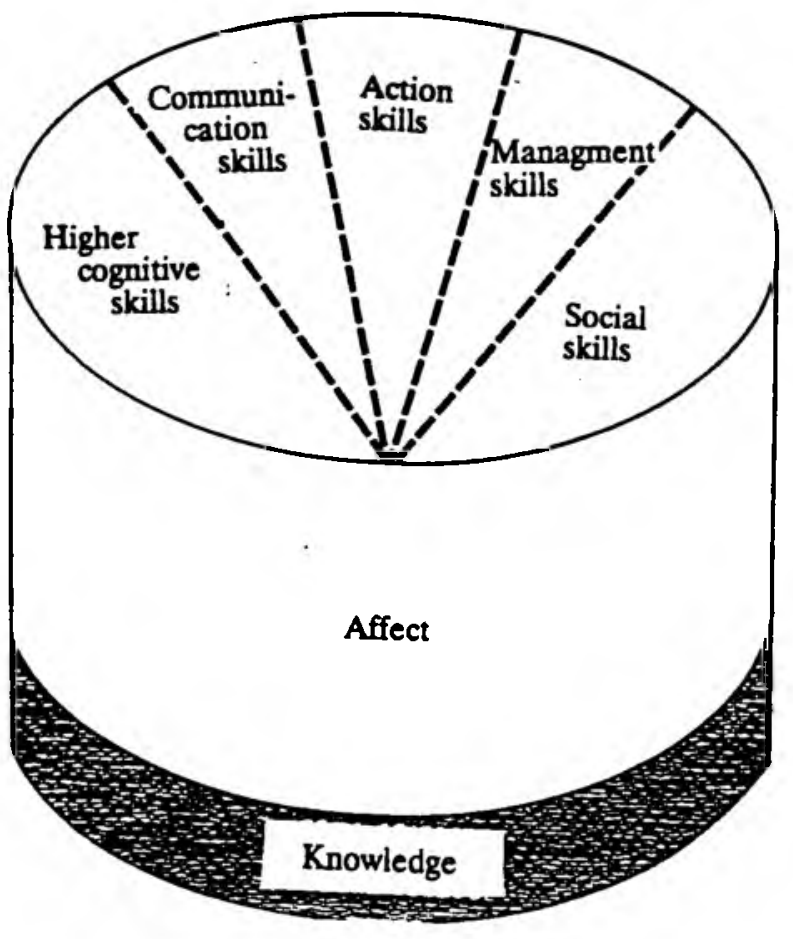

FIGURE 2: THE COMPONENTS OF NURSING SKILLS 


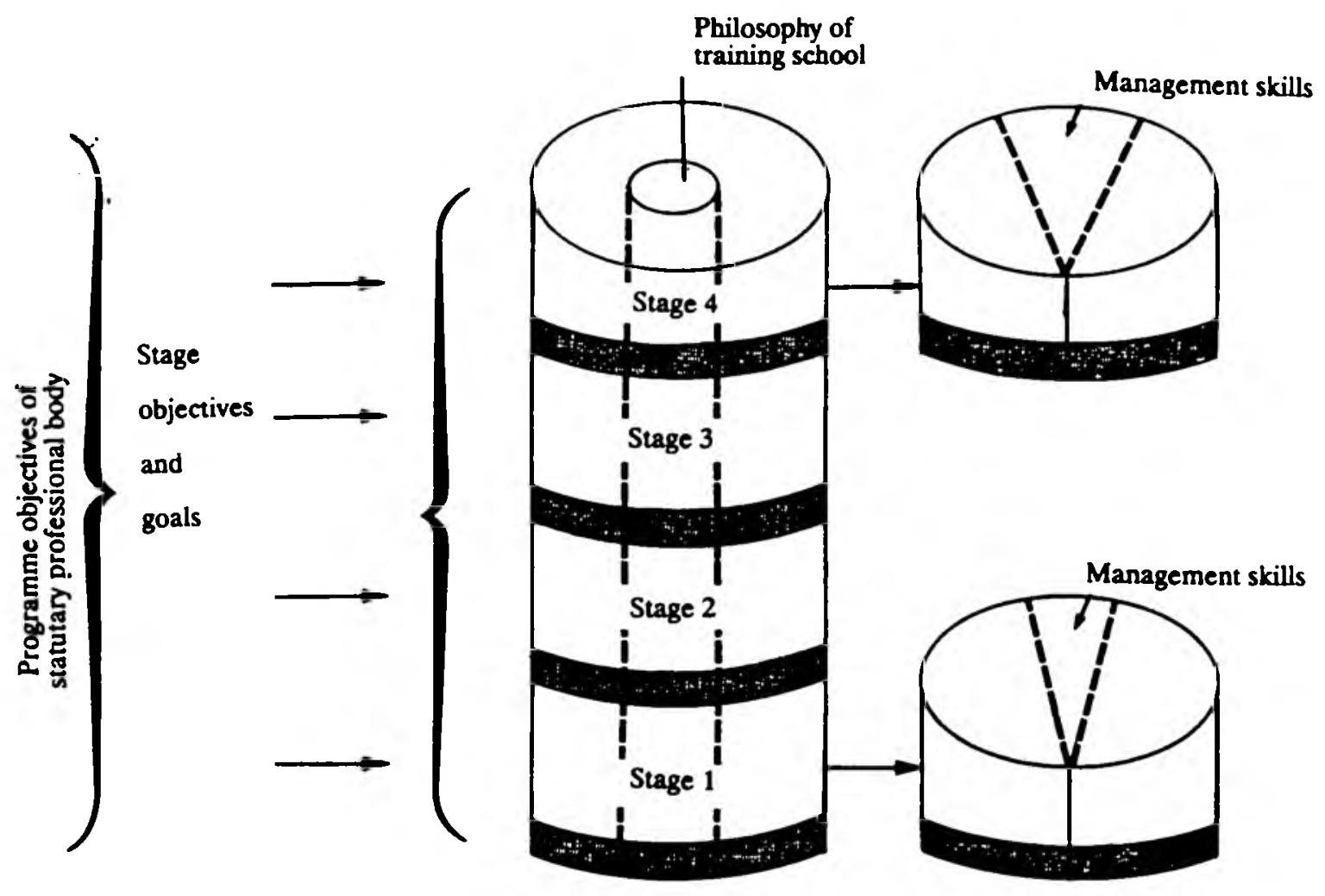

FIGURE 3: DIAGRAMMATIC REPRESENTATION OF THE STAGES OF A CLINICAL TRAINING PROGRAMME

Apart from the basic communication skills, the ability of health care workers to use therapeutic interactions effectively is vital. This means that communication must be goal-directed and consciously planned to promote the patient's health and welfare.

In the second place it refers to the ability to conduct an interview, and collect data during personal contact with a health care consumer.

Thirdly, it refers to written communication, that is, the ability to transmit information in writing, in a style which is simple, succinct, clear, consistent, logical, structured, accurate and balanced.

It refers, in the fourth place, to the ability to instruct health care consumers, the ability to identify learning opportunities and to teach students.

Psychomotor skills comprise action or behaviour that demands neurologically coordinated muscular activity (Reilly 1980:68; Field et al. 1984:286; Abbatt \& McMahon 1985:179). The actions must be performed in such a way that progress towards their mastery is clearly observable. These stills include the performance of techniques such as physical examination, observation, measuring central venous pressure, the administration of intramuscular injections, etc.

It must be emphasized that the performance of psychomotor skills must be evaluated in the context of total patient care. In other words, the focus should not be only on the procedure as such, but should include the indication for the procedure, the assessment and planning which preceded it, and the interpretation of data obtained during the procedure.

Management skills comprise the ability to plan, organize, direct and control.

Social skills include skills such as cooperation, negotiation, counselling and persuasion (Carter 1985:143).

C. Affect refers to values, feelings, attitudes, appreciation, interest and other affective aspects of personality. It also includes one's attitude to self, one's work and others (Bloom et al. 1971:7).

In Figure 2 the various components of skills are represented by means of dotted lines which indicate the overlapping of the components. For instance, planning is a higher cognitive skill, but also an important management skill. Planning also forms part of the preparation for performing a psychomotor procedure.

The researcher believes that it is not possible to divide the components into mutually exclusive classifications because of the complexities of human behaviour and clinical competence.

The size of a facet or component of clinical competence (in relation to the rest) will vary from stage to stage, for instance, first or second academic year, because it is determined by the stage objectives or the objectives of the curriculum. For example, the component of management skills evaluated in stage one may be very small compared with the same component evaluated in stage four (see Figure 3).

Balance must be maintained among the various facets and components (seen as a whole), during the training programme. One particular component or facet of a programme should not be regarded as more important than another.

The four stages of a clinical training programme are illustrated in Figure 4. The philosophy ${ }^{2}$ of the training school forms the mainstay of the curriculum.

It would be ideal if every facet or component of clinical competence were to be evaluated in each stage of the training programme, instead of as a vertical strand from stage one to stage four. This means that each of the stages would build on the previous one, which would represent a continuum of competencies becoming more complex and abstract in each stage.

Although clinical competencies are classified and can be evaluated separately, nursing is far

2 This is a document delineating the values of the educators of a particular tertiary educational intitution. It contains clear and unambiguous statements regarding important aspects of the realities of nursing education, such a beliefs about learning, evaluation and a view of man. 


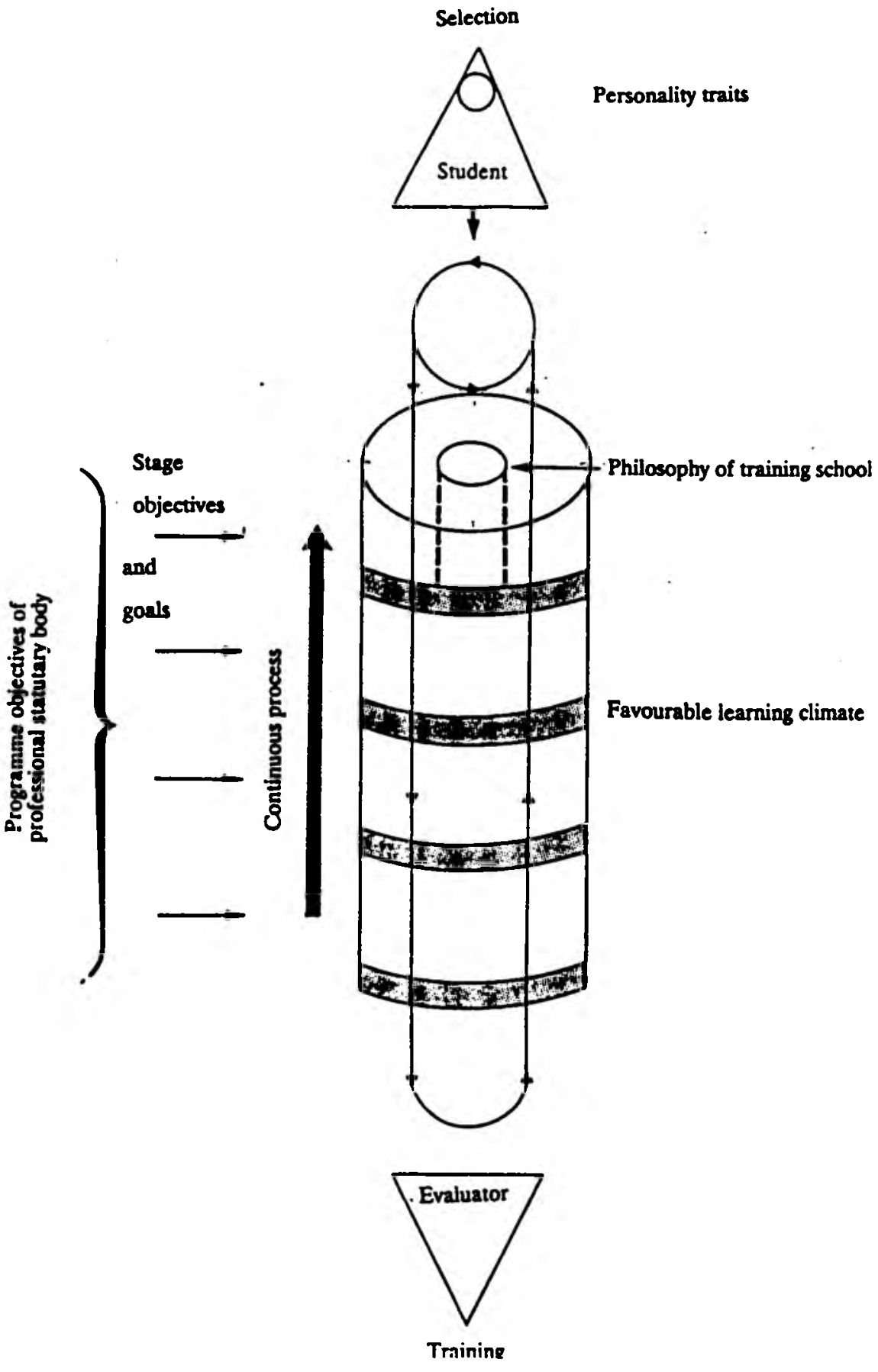

FIGURE 4: A DIAGRAMMATIC REPRESENTATION OF CLINICAL EVALUATION

more than the mere performance of individual skills or a specific effect. It is, among others, the application of a scientific problem-solving process known as the nursing process, and the ability to function as a self-reliant. independent nurse practitioner.

For this resoon it is essentiol that nursing should be evaluated as a whole in actual clinical practice to enure safe standards of nursing practice.

\section{Personality traits}

Since nursing is a profession, it is important that the personality characteristics of student
(Halcomb 1976:200; Madigan \& La Duca 1978:208; Ewan \& White 1984:200). Because of the complexity of clinical competence and the limited suitability of individual methods and techniques, a combination of evaluation strategies are called for (Reilly 1980:98).

Evaluation instruments must be drawn up Jointly by the evaluators who are going to use them, for the situations in which they are to be used. They must be valid and reliable and should preferably be tested before use (Uys 1982:90; Abbat \& McMahon 1985:90).

Since no perfect evaluation instrument exists, instruments must be evaluated and improved after every implementation in practice (Morgan \& Irby 1978:xii).

Clinical evaluation must be performed against previously formulated objectives

Objectives are useful because they form a basis for the selection or design of evaluation methods and techniques. Furthermore, the success of clinical instruction can be evaluated againt them, and, in the third place, they help students to direct their own activities towards reaching clinical instruction objectives (Reilly 1980:166; Brozenec et al. 1987:43)

Clinical evaluation must take place in actual or simulated clinical practice (Irby, Evans \& Larson 1978:23) or only in actual clinical practice

In the interests of safe nursing practice standards and because of the complexity of clinical competence, evaluation in simulated circumstances alone, is unacceptable (Madigan \& La Duca 1978:206).

The complete model of clinical evaluation is diagramatically represented in Figure 4.

\section{Propositions and definitions}

Eighteen propositions were derived from the model, and all concepts were defined to eliminate any ambiguity (Mulder, 1990:249-253).

\section{CONCLUSION}

As model construction and theorizing are not a passive but adynamic process, the researcher plans to continue to refine and develop the model. 


\section{REFERENCES}

ABBATT, F. \& McMAHON, R. 1985. Teaching health-care workers. A practical guide. London: MacMillan.

ABBOT, S.D., CARSWELL, R., McGUIRE, M. \& BEST, M. 1988. Self-evaluation and its relationship to clinical evaluation. Journal of Nursing Education, 27,5,219-224.

ANDERSON, E. \& KNUTESON, C 1990. Co-assessment as a unique approach to measuring students' clinical abilities. Journal of Nursing Education, 29,1,42-43.

BLOOM, B.S. ed. 1974. Taxonomy of educational objectives. London: Longman.

BROZENEC, S., MARSHALL, J.R., THOMAS, C. \& WALSH, M. 1987. Evaluating borderline students. Journal of Nursing Education, 26,1,42-44.

CARTER, J.H., HILLIARD, M., CASTLES, M.R., STOLL, L.D. \& COWAN, A. 1972. Standards of nursing care. New York: Springer Publishing Company.

EWAN, C. \& WHTE, R. 1984. Teaching nursing. A self-instructional handbook. London: Croom Helm.

FIELD, W.E., GALLMAN, F.L.V., NICHOLSON. R. \& DREHER, M. 1984. Clinical competencies of baccalaureate students. Journal of Nursing Education, 23,7,284-293.

FLAGLER, LOPER-POWERS, S. \& SPITZER, A. 1988. Clinical teaching is more than evaluation alone! Joumal of Nursing Education, 27,8,342-348.

FUHRMANN, B.S. \& WEISSBURG, M.J. 1978. Self-assessment. In Evaluating clinical competence in the health professions. Comp. by M.K. Morgan and D.M. Irby. Saint Louis: C.V.Mosby 139-150.

GENTILE, J.R. \& STEVENS-HASLINGER, C. 1983. A comprehensive grading scheme. Nursing Outlook, 31,1,49-54.

GUILBERT, J.J. 1981. Educational handbook for health personnel. Geneva: World Health Organization.
HALCOMB, J.D. 1976. Test construction. In Teaching in the health profession. Ed. by C.W. Ford and M.K. Morgan. Saint Louis: C.V. Mosby 198-207.

IRBY, D.M., EVANS, J. \& LARSON, L. 1978b. Trends in clinical evaluation. In Evaluation clinical competence in the health professions. Comp. by M.K. Morgan and D.M. Irby. Saint Louis: C.V. Mosby 20-29.

JACKSON, R. 1987. Approaching clinical teaching and evaluation through the written word: A humanistic approach. Journal of Nursing Education, 26,9,384-385

KANE, M.T. 1980 Measurement theory. In Measurement and evaluation in nursing education. New York: National League for Nursing. 7-26.(pub.no. 17-1807)

KARUHIJE, H.F. 1986 . Educational preparation for clinical teaching: Perceptions of the nurse educator - Journal of Nursing Education, 25,4,137-143.

KEHOE, D.M. \& HARKER, T. 1979. Principles of assessing nursing skills. London: Pitman Medical.

KOTZÉ, W. 1984. Professionele gevormdheid van die studentverpleegkundige. CURATIONIS, 7,1,17-22.

KRUGER, R.A. 1980. Beginsels en kriteria vir kurrikulumontwerp. Pretoria: HAUM.

LITWACK, L., SAKATA, R. \& WYKLE, M. 1972. Counselling, evaluation and student development in nursing education. Philadelphia: W.B. Saunders Company.

MADIGAN, M.J. \& LA DUCA, A. 1978 Higher levels of learning. In Clinical education for the allied health professions. Ed. by C.W. Ford. Saint Louis: C.V. Mosby.

MELLISH, J.M. \& JOHNSTON, S.U. 1986. Evaluation in clinical nursing. Durban: Butterworths.

MORGAN, M.K. \& IRBY, D.M. 1978. Evaluating clinical competence in the health professions. Saint Louis: C.V.Mosby.
MOUTON, J., MARAIS, H.C., PRINSLOO, K.P. \& RHOODIE, N.J.1988. Metodologie van die geesteswetenskappe: Basiese begrippe. Pretoria: Raad vir Geesteswetenskaplike Navorsing.

MULDER, M. 1990. 'n Ondersoek na kliniese evaluering in Verpleegkunde aan Suider-Afrikanse univeriteite. Bloemfontein: Universiteit van die Oranje-Vrystaat.

REILLY, D.E. 1980. Behavioural objectives in nursing: Evaluation of learner attainment. New York: Appleton-Century-Crofts.

ROBERTSON, C.M. 1980. Clinical teaching. Melbourne: Pitman Medical.

SOMMERFELD, D.P. \& ACCOLA, K.M 1978. Evaluating students' performance. Nursing Outlook, 26,7,432-436.

UYS, L.R. 1982. Kurrikulumontwikkeling in verpleegkunde, Bloemfontein: P.J. de Villiers.

WOOLF, PJ. 1984. Increasing self-esteem through self-evaluation. Journal of Nursing Education. 23,2,78-80.

WOOLLEY, A.S. 1977. The long and tortured history of clinical evaluation. Nursing Outlook, 25,5,308-315.

\section{ACKNOWLEDGEMENTS}

The researcher acknowledges the help of Elzabe Gleeson for typing the manuscript. Celia Roetz for drawings and Miss MV Vermaak for the English translation of the manuscript.

\begin{tabular}{c}
\hline Dr Magda Mulder \\
DSoc Sc.(Nursing) \\
Senior Lecturer \\
Department of Nursing \\
University of the Orange Free State \\
\hline
\end{tabular}

